\title{
PERANCANGAN ALAT PENGUKUR TINGGI DAN BERAT BADAN IDEAL BERBASIS ARDUINO
}

\author{
Dirman Nurlette ${ }^{1}$,Toni Kusuma Wijaya \\ Program Studi Teknik Elektro, Fakultas Teknik \\ Universitas Riau Kepulauan \\ Batam \\ dirmannurlette12@gmail.com ${ }^{1}$, tonikusuma26@yahoo.co.id ${ }^{2}$
}

\begin{abstract}
ABSTRAK
Alat pengukur tinggi badan dan berat badan yang sekaligus memberikan informasi berat badan ideal akan sangat bermanfaat bagi para pengguna. Oleh karena itu, dalam penelitian ini, dirancang dan direalisasikan suatu alat ukur yang sekaligus dapat mengukur tinggi badan dan berat badan serta memberikan informasi ideal atau tidaknya berat badan yang terukur. Alat ukur ini menggunakan Arduino Uno sebagai otaknya, sensor ultrasonik untuk mengukur tinggi badan, dan sensor load cell untuk mengukur berat badan. Data dari kedua sensor tersebut diolah oleh Arduino untuk mendapatkan indeks massa tubuh (IMT) dan berat badan ideal (BBI). Nilai tinggi badan, berat badan, dan berat badan ideal akan ditampilkan pada LCD.
\end{abstract}

Kata kunci: Alat ukur, tinggi badan, berat badan, Arduino, utrasonik, load cell.

\section{PENDAHULUAN}

\section{A. Latar Belakang}

Perkembangan Teknologi Informasi

dan Komunikasi yang sangat cepat berkembang pada era sekarang ini telah memberikan dampak globalisasi, persaingan bisnis, tuntutan pekerjaan, dan pola kehidupan manusia yang semakin meningkat. Kemajuan teknologi menyebabkan manusia menciptakan banyak alat yang dapat membantu meringankan suatu pekerjaan yang dilakukan. Salah satunya adalah dengan terciptanya alat yang digunakan sebagai pengukur tinggi dan berat badan manusia. Mengukur berat badan, manusia cukup menaiki alatnya saja. Sedangkan untuk mengukur tinggi badan,pada umumnya manusia masih dilakukan secara manual dengan menggunakan alat ukur seperti meteran dan penggaris.

Dalam perancanagan ini akan membuat suatu alat yang akan mengukur tinggi badan dan berat badan ideal secara otomatis dengan memanfaatkan mikrokontroler sebagai pengendali dari alat yang akan dirancang, dalam penilitian perancangan ini penulis akan membedahkan beberapa hal diantaranya LCD yang 
digunkan yaitu 20x4 dan push button sebagai pilihan jenis kelamin. Untuk mengukur tinggi dan berat badan pada umumnya sudah dilakukan secara otomatis, dalam hal ini pengukuran secara otomatis untuk tinggi dan berat badan dilakukan dengan menggunkan alat yang berbeda. Disamping itu hasil pengukuran baik tinggi badan maupun berat badan sudah dibaca dengan teliti oleh sensor yang digunakan.

Berdasarkan permasalahan yang dikemukakan diatas, Penelitian ingin membuat "Perancangan Alat Pengukur Tinggi Dan Berat Badan Ideal Berbasis Arduino". sebagai juduli penelitian. Dengan maksud agar waktu yang digukanan manusia lebih efisien untuk mengetahui tinggi dan berat badan ideal dengan menggunakan alat ini nantinya.

\section{B. Tujuan Penilitian}

Semua penelitian yang dilakuan atau dilaksanakan pasti mempunyai maksud atau tujuan tertentu . Begitu juga dengan Penelitian yang akan dilakukan kali ini diharapkan mampu mencapai tujuan yang diinginkan. Penelitian kali ini mempunyai tujuan yaitu :

Untuk merancang suatu alat pengukur tinggi dan berat badan ideal berbasis arduino.

\section{LANDASAN TEORI}

Penjelasan dan uraian teori yang digunakan dalam pembuatan alat diperlukan untuk mempermudah pemahaman cara kerja rangkaian dan dasar perancangan pembuatan alat. Teori yang akan dijelaskan dalam penulisan ini meliputi arduino uno, sensor load cell, sensor ultrasonik, push button, dan LCD 20x4.

\section{A. Kegunaan BMI}

BMI (body mass index) adalah salah satu indikator kadar relatif lemak tubuh seseorang yang sudah dewasa dengan usia 20 tahun ke atas. BMI digunakan untuk menentukan status berat badan seseorang apakah seseorang memiliki badan yang terlalu kurus, ideal, atau terlalu gemuk.

Untuk menghitung angka BMI seseorang maka perlu diketahui berat badan orang tersebut dalam satuan kilogram (kg) dan tinggi badannya dalam satuan meter (m).

Tabel 1 Klasifikasi Nilai BMI [9]

\begin{tabular}{|l|l|}
\multicolumn{1}{|c|}{ Status Gizi } & \multicolumn{1}{c|}{ BMI } \\
\hline Kekurangan Berat & $<18,5$ \\
\hline Ideal & $18.5-24,9$ \\
\hline Kelebihan Berat & $25-30$ \\
\hline Gemuk & $30-40$ \\
\hline $\begin{array}{l}\text { Gemuk Tidak } \\
\text { Sehat }\end{array}$ & $>40$ \\
\hline
\end{tabular}

\section{B. Arduino Uno}

Arduino Uno adalah papan sirkuit berbasis mikrokontroler ATmega328. IC (integrated circuit) ini memiliki 14 input/output header digital (6 output untuk PWM), 6 analog input, resonator kristal keramik $16 \mathrm{MHz}$, Koneksi USB, soket adaptor, pin ICSP, dan tombol reset. arduino juga mempunyai bahasa pemrogramanya sendiri yang berupa bahasa C. Selain itu dalam board arduino sendiri sudah terdapat loader yang berupa USB sehingga memudahkan kita ketika kita memprogram mikrokontroler didalam arduino. Sedangkan pada kebanyakan board mikrokontroler yang lain yang masih membutuhkan rangkaian loader terpisah untuk memasukkan program ketika kita memprogram mikrokontroler. Port USB tersebut selain untuk loader ketika 
memprogram, bisa juga difungsikan sebagai port komunikasi serial.

a). Perangkat Keras (papan masukan / luaran)

Dengan mengambil contoh sebuah papan Arduino tipe USB, bagian-bagiannya dapat dijelaskan sebagai berikut :

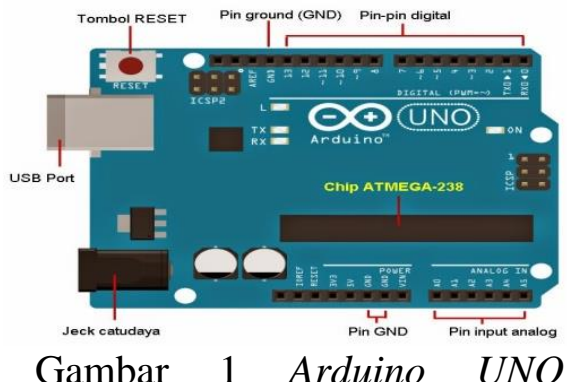

\section{ATmega328}

Gambar 1 Arduino UNO R3

\section{USB}

Berfungsi untuk memuat program dari komputer ke dalam papan, Komunikasi Serial antara papan dan komputer dan Memberi daya listrik kepada papan.

2. Power (Jack Catudaya)

Papan Arduino dapat juga diberi catu daya secara langsung dari sumber daya AC dengan menghubungkannya ke Barrel Jack.

\section{Tombol reset}

Berfungsi untuk me-reset papan sehingga program akan mulai lagi dari awal.

Perhatikan bahwa tombol reset ini bukan untuk menghapus program atau mengosongkan mikrokontroler.

\section{Pin Ground (GND)}

Ada beberapa pin GND pada Arduino, salah satunya dapat digunakan untuk menghubungkan ground rangkaian.

5. pin Analog

Papan Arduino Uno memiliki lima pin input analog A0 sampai A5. Pin-pin ini dapat membaca sinyal dari sensor analog seperti sensor kelembaban atau temperatur dan mengubahnya menjadi nilai digital yang dapat dibaca oleh mikroprosesor.

6. pin Digital
Papan Arduino Uno memiliki 14 pin I/O digital (15), 6 pin output menyediakan PWM (Pulse Width Modulation). Pin-pin ini dapat dikonfigurasikan sebagai pin digital input untuk membaca nilai logika (0 atau 1) atau sebagai pin digital output untuk mengendalikan modul-modul seperti LED, Pin yang berlabel

dapat digunakan untuk membangkitkan PWM.

7. Main microcontroller

Setiap papan Arduino memiliki Mikrokontroler (11). Kita dapat menganggapnya sebagai otak dari papan Arduino. IC (integrated circuit) utama pada Arduino sedikit berbeda antara papan arduino yang satu dengan yang lainnya. Mikrokontroler yang sering digunakan adalah ATMEL.

a). Perangkat Lunak (Arduino IDE)

Sehubungan dengan pembahasan untuk saat ini, perangkat lunak Arduino yang akan digunakan adalah driver dan IDE, walaupun masih ada beberapa perangkat lunak lain yang sangat berguna selama pengembangan Arduino. IDE Arduino adalah perangkat lunak yang sangat canggih ditulis dengan menggunakan Java. IDE Arduino terdiri dari

1. Uploader, sebuah modul yang memuat kode biner dari komputer ke dalam memory di dalam papan Arduino.

2. Editor program, sebuah window yang memungkinkan pengguna menulis dan mengedit program dalam bahasa Processing.

3. Compiler, sebuah modul yang mengubah kode program (bahasa Processing) menjadi kode biner. Bagaimanapun sebuah mikrokontroler tidak akan bisa memahami bahasa Processing. 
Bahasa yang bisa dipahami oleh mikrokontroler adalah kode biner. Itulah sebabnya compiler diperlukan dalam hal ini.

\section{Sensor Ultrasonik HC-SRF04 (Sensor Jarak)}

Sensor HC-SR04 adalah sensor pengukur jarak berbasis gelombang ultrasonik. Prinsip kerja sesnsor ini dengan radar ultrasonik. Gelombang ultrasonik di pancarkan kemudian di terima balik oleh receiver ultrasonik. Jarak antara waktu pancar dan waktu terima adalah representasi dari jarak obyek. Sensor ini cocok untuk aplikasi elektronik yang memerlukan deteksi jarak termasuk untuk sensor pada robot.

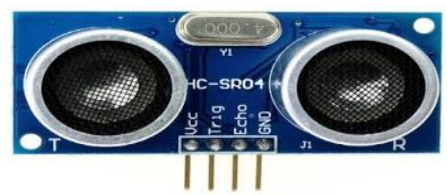

Gambar 2 sensor ultrasonik HC-SR04

Sensor HC-SR04 adalah versi low cost dari sensor ultrasonic PING buatan parallax. Perbedaaannya terletak pada pin yang digunakan. HC-SR04 menggunakan 4 pin sedangkan PING buatan parallax menggunakan 3 pin. Pada Sensor HC-SR04 pin trigger dan output diletakkan terpisah. Sedangkan jika menggunakan PING dari Parallax pin trigger dan output telah diset default menjadi satu jalur. Tidak ada perbedaaan signifikan dalam pengimplementasiannya. Jangkauan karak sensor lebih jauh dari PING buatan parllax, dimana jika ping buatan parllax hanya mempunyai jarak jangkauan maksimal 350 cm sedangkan sensor HC-SR04 mempunyai kisaran jangkauan maksimal 400-500cm.

\section{Sensor Berat (Load Cell)}

Load cell adalah sebuah alat uji perangkat listrik yang dapat mengubah suatu energi menjadi energi lainnya yang biasa digunakan untuk mengubah suatu gaya menjadi sinyal listrik. Perubahan dari satu sistem ke sistem lainnya ini tidak langsung terjadi dalam dua tahap saja tetapi harus melalui tahap-tahap pengaturan mekanikal, kekuatan dan energi dapat merasakan perubahan kondisi dari baik menjadi kurang baik.

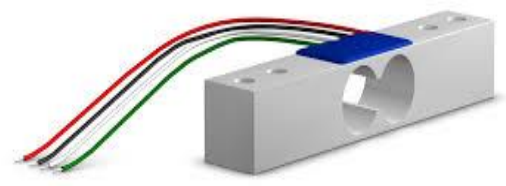

Gambar 3 Bentuk fisik load cell

Pada strain guage (load cell) atau biasa disebut dengan deformasi strain gauge. The strain gauge mengukur perubahan yang berepengaruh pada strain sebagai sinyal listrik, karena perubahan efektif terjadi pada beban hambatan kawat listrik. Sebuah sel/slot beban umumnya terdiri dari empat aspek pengukur regangan dalam sistem konfigurasi pada Wheatstone Bridge. Sel/slot beban dari satu strain gauge atau dua pengukur regangan.

Output sinyal listrik biasanya disediakan serta di urutankan beberapa milivolt dan membutuhkan amplifikasi oleh penguat instrumentasi sebelum dapat digunakan. Output dari pemantauan perubahan kondisi dapat ditingkatkan untuk menghitung gaya yang diterapkan untuk perabaikan dan pemantauan kondisinya. Berbagai jenis sel/slot beban yang ada termasuk sel/slot beban hidrolik,

Strain gauge merupakan bagian terpenting dari sebuah load cell, dengan fungsi untuk mendeteksi besarnya perubahan dimensi jarak yang disebabkan oleh suatu elemen gaya. Strain gauges secara umum digunakan 
dalam pengukuran presisi gaya, berat, tekanan, torsi, perpindahan dan kuantitas mekanis lainnya. Setelahnya dikonversi menjadi energi tegangan kedalam anggota mekanis. Strain gauge menghasilkan perubahan pada nilai tahanan yang proporsional dengan perubahan jangka panjang atau perubahan melalui lamanya proses.

Load cell merupakan alat pengujian dan perangkat untuk membantu kinerja dan komopnen pada sensor load cell (strain gauge). Gambar dibawa ini adalah prinsip kerja ketika load cell bekerja.

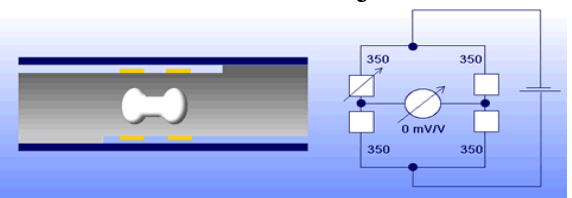

Gambar a) Rangkaian Load Cell tanpa beban

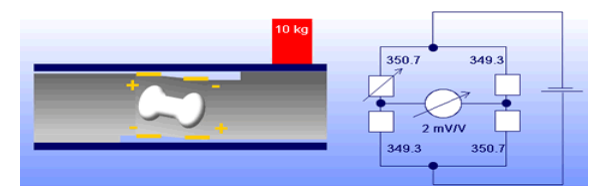

Gambar b) Rangkaian Load Cell diberi beban

Gambar 4 perubahan pada load cell

\section{E. HX711 Amplifier}

HX711 adalah sebuah komponen terintegrasi dari "Avia Semi Conductor", HX711 presisi 16-bit analog to digital conventer (ADC) yang didesain untuk sensor timbangan digital dalam industrial control aplikasi yang terkoneksi sensor jembatan (datasheet HX 711).

\section{Gambar 5 HX711 Amplifier}

Setelah load cell mengirimkan hasil timbang yang melebihi batas maksimal berat yang berbentuk sinyal analog maka di rubah menjadi bentuk sinyal digital. Pin DOUT dan PD_SCK mendapat inputan dari load cell dimana weight sensor module akan merubah dari sinyal analog menjadi sinyal digital dengan bentuk seperti getaran pulsa pulsa 1,2 dan seterusnya .

\section{F. LCD 20x4 ( Liquid Crystal Display )}

LCD (Liquid Cristal Display) berfungsi untuk menampilkan karakter angka, huruf ataupun simbol dengan lebih baik dan dengan konsumsi arus yang rendah. Dalam aplikasinya, LCD $20 \times 4$ terbagi menjadi beberapa bagian bentuk, ada yang memakai backlight, ada juga yang tidak. Kemudian yang memakai backlight, ada yang berwarna hijau dan ada juga yang berwarna biru. Tapi intinya sama, pin yang digunakan sama.

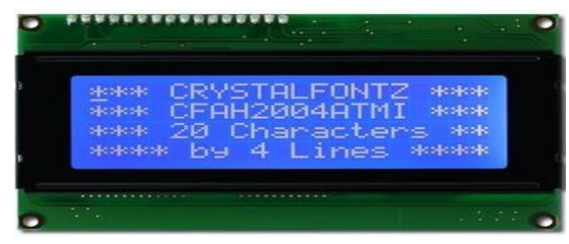

Gambar 6 LCD 20x4

\section{G. Potensiometer}

Potensiometer pada dasarnya berfungsi sebagai pembagi tegangan variabel. Potensio merupakan salah satu jenis yang Nilai Resistansinya dapat diatur sesuai dengan kebutuhan Rangkaian Elektronika ataupun kebutuhan pemakainya.

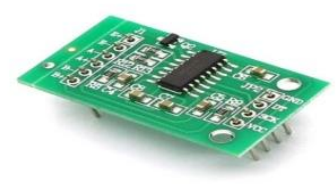




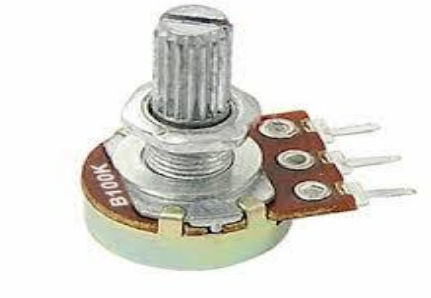

Gambar 7 Potensiometer

\section{H. Pin Header}

Untuk menghubungkan LCD dengan kabel jumper maka perlu pin header, jadi pin header di solder ke bagian LCD agar kabel jumper dapat dihubungkan ke LCD.

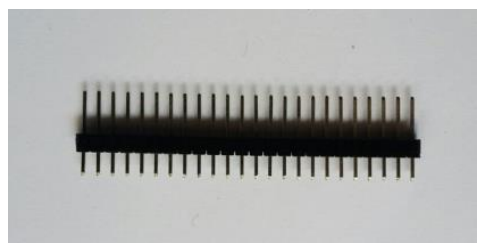

Gambar 8 Pin Header

\section{METODOLOGI PENELITIAN}

\section{A. Metodologi Penilitian}

Pada penelitian ini membahas tentang perancangan dan pembuatan alat pengukur tinggi dan berat badan secara ideal yang berbasis arduino. Perancangan alat ini meliputi perancangan perangkat keras (hardware) dan perangkat lunak (software). Maka dalam proposal ini penyajian dibagi atas beberapa bagian yaitu :

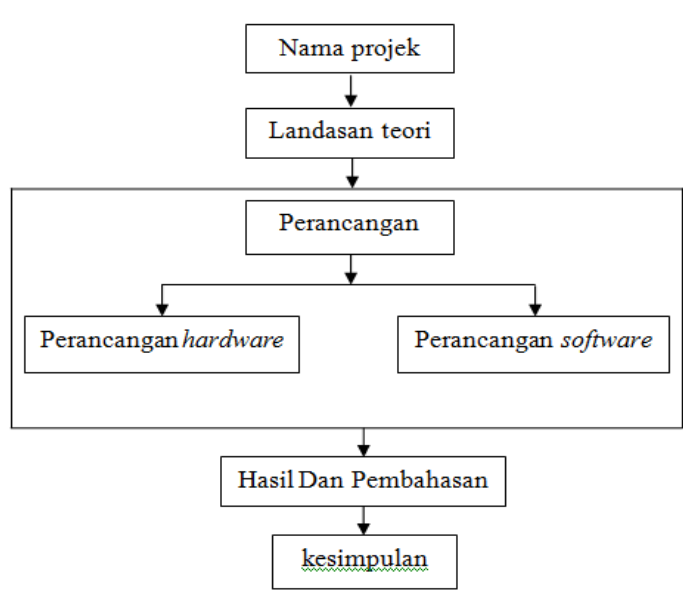

Gambar 8 Kerangka Metodologi Penilitian

\section{B. Perancangan Hardware dan Sofware}

Dalam proses pembuatan perancangan alat pengukur tinggi dan berat ideal berbasis arduino, harus digambarkan terlebih dahulu menggunakan blok diagram tentang konfigurasi yang akan diterapkan. Hal ini akan sangat membantu dalam mengetahui kesalahan serta kelemahan jika terjadi kegagalan dalam perancangan sistem tersebut. Selain itu blok diagram juga akan membantu untuk memahami perancangan alat yang akan dilakukan.

\section{Perancangan Hardware}

Perancangan Hardware disusun menggunakan layout dari arduino uno yang sudah dipatenkan. Sehingga peneliti hanya menentukan fungsi pin yang akan digunakan untuk disambungkan dengan komponen yang dibutuhkan.

\section{Blok Diagram}

Blok diagram dari Perancangan Alat Pengukur Tinggi dan Berat Ideal Berbasis arduino dapat dilihat pada gambar 9 berikut ini. 


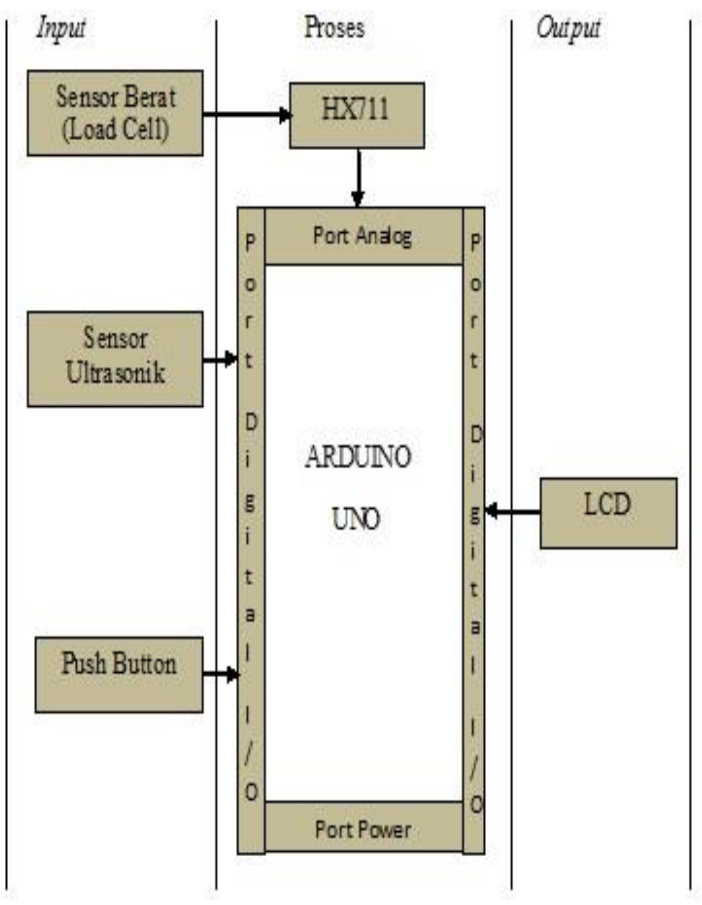

Gambar 9 Blok diagram perancangan alat

\section{Input}

Input menggunakan 2 buah sensor, yaitu sensor ultrasonik HC-SRF04 dan sensor berat (load cell). sensor ultrasonic HC-SRF04 berfungsi untuk mengukur tinggi dari obyek dengan cara mengukur jarak antara sensor ultrasonik dengan tinggi permukaan, Sensor berat (load call) berfungsi untuk mengukur berat badan dari obyek tersebut. Blok input Load Cell dan Sensor Ultrasonik HY-SRF04. Load cell dihubungkan pada port GND dan $5 \mathrm{~V}$ arduino uno. Port GND merupakan ground atau tegangan negatif, sedangkan port $5 \mathrm{~V}$ merupakan tegangan positif yang mengalir sebesar 5 Volt.

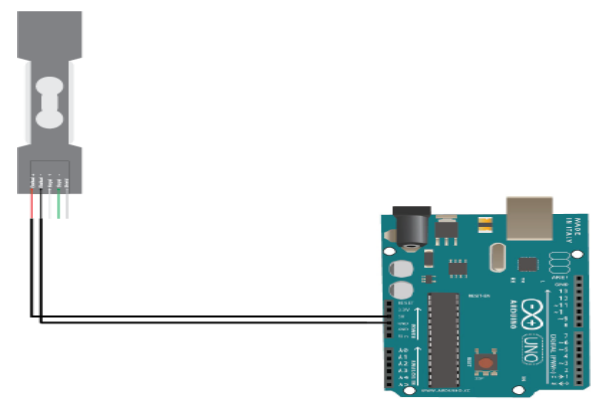

Gambar 10 Rangkaian Load Cell

Sensor Ultrasonik HY-SRF04 dihubungkan pada port GND, 5V, Pin 6 dan Pin 7 arduino uno. Port GND merupakan ground atau tegangan negatif, port $5 \mathrm{~V}$ merupakan tegangan yang mengalir sebesar 5 Volt, sedangkan Pin 6 dan 7 merupakan output PWM 8-bit dengan menggunakan fungsi analog Write, push button yang fungsinya sebagai pilihan jenis kelamin yang dihubungkan ke pin 5 dan pin 3.

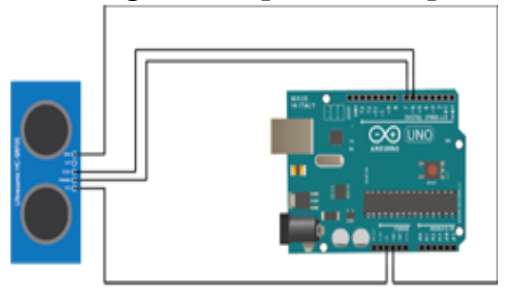

Gambar 11 Rangkaian Sensor Ultrasonik HY-SRF04

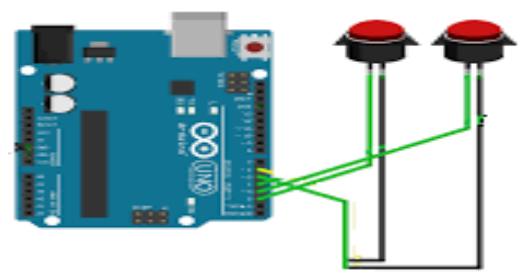

Gambar 12 Rangkaian push button

2. Proses

Bagian proses ini terdapat pada mikrokontroler dan HX711, arduino berfungsi untuk memproses seluruh intruksi, baik itu memproses data masukan dari sensor berat (load cell) dan HX711, serta 
sensor ultrasonik SRF04 yang kemudian hasilnya teruskan pada LCD (Liquid Crystal Display) sebagai penampil hasil dan tombol menu (Push Button) sebagai tumbol pilihan jenis kelamin. HX711 berfungsi untuk menerima inputan data dari load cell yang kemudian dikirim ke arduino untuk diproses kembali. Blok proses merupakan blok yang memproses masukan data yang berasal dari blok input agar mendapatkan output data yang sesuai keinginan. Blok proses ini menggunakan rangkaian arduino uno dan HX711. Rangkaian HX711 terdapat 10 pin, 6 pin input dan 4 pin output. Dimana inputan data berupa data analog dan outputnya berupa data digital.

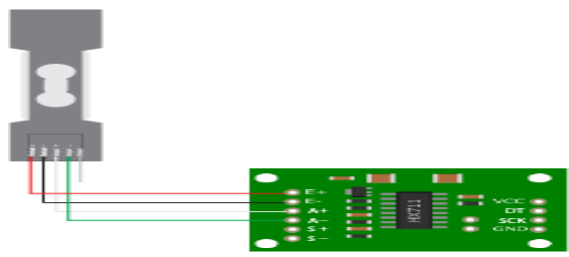

Gambar 13 Rangkaian HX711

Sedangkan rangkaian arduino uno menyediakan 20 pin input/output, dimana terdapat 14 digital input/output pin, 6 pin input analog (ADC). Terdapat juga 5 pin power yang berguna untuk mengatur tegangan yang masuk.

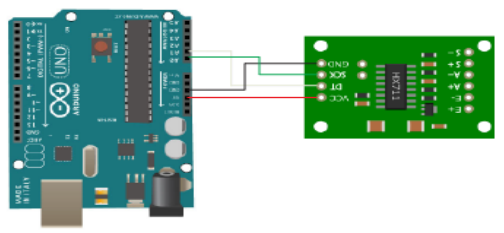

Gambar 14 Rangkaian Arduino Uno

\section{Output LCD}

Blok output menggunakan LCD (Liquid Crystal Display) untuk menampilkan hasil output data berupa huruf dan angka. LCD berada dibawah kendali dari arduino uno, dimana tampilan pada LCD nantinya berasal instruksi atau perintah program yang masuk pada arduino tersebut.

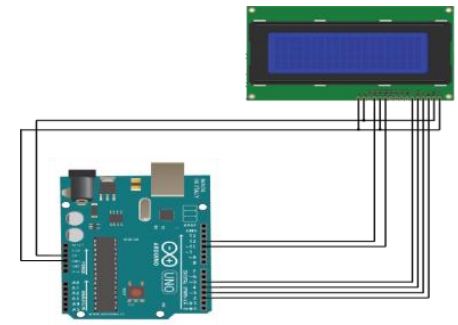

Gambar 15 Rangkaian LCD

\section{F. Skematik Rangkaian}

Skematik rangkaian alat pengukur tinggi dan berat badan ideal ini adalah gambaran suatu rangkaian yang memberikan cara kerja yang detail, mulai dari symbol sampai dengan koneksi rangkaian satu ke rangkaian lainnya. yang terlihat pada gambar 16

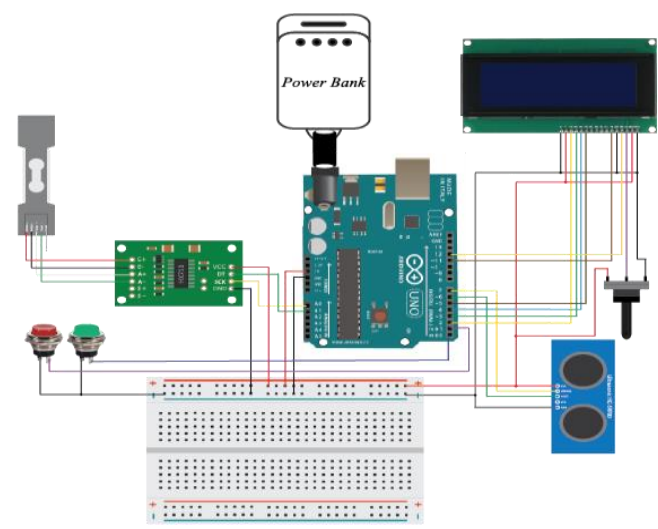

Gambar 16 Skematik rangkaian alat ukur tinggi dan berat badan ideal

\section{G. Diagram alir alat pengukur tinggi dan berat badan ideal}

Rancangan perangkat lunak yang berfungsi untuk mengatur kinerja keseluruhan dari sistem yang terdiri dari beberapa perangkat keras sehingga sistem ini dapat bekerja dengan baik. Diagram alir program utama ditunjukkan dalam Gambar 17 


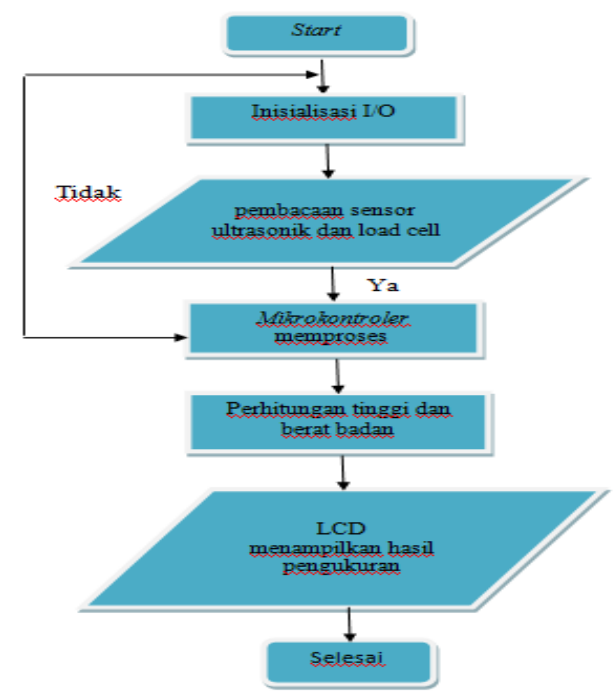

Gambar 17 Diagram alir alat pengukur tinggi dan berat badan ideal

Berdasarkan diagram alir alat pengukur tinggi dan berat badan ideal berbasis arduino pada gambar 18 maka dapat jelaskan sebagai berikut. Dapat dijelaskan bahwa ketika sistem akan mulai dalam pilihan tombol menu jenis kelamin, kemudian sistem akan menjalankan fungsi. Maksdunya dari menjalankan fungsi yaitu menjalankan fungsi dari sensor ultrasonik sebagai pengukur tinggi dan load cell sebagai pengukur berat, serta arduino sebagai otak dari semua proses yang akan dijalankan. Sensor berat (load cell) akan menghitung beban dan sensor ultrasonik akan mengitung tinggi dari obyek. Perhitungan tersebut akan diproses melalui mikrokontroler, setelah itu outputnya akan ditampilkan pada LCD. Langkah selanjutnya adalah menghitung berat badan ideal (BBI) dan Indeks Massa Tubuh (IMT). Perhitungan IMT merupakan perbandingan dari hasil berat dan tinggi badan. Setelah hasil IMT didapatkan, maka hasil tersebut akan dibandingkan dengan standar IMT yang telah ditetapkan, Output dari proses perhitungan IMT tersebut akan ditampilkan pada LCD.

\section{H. Rancangan Mekanis Alat}

Pada perancangan alat ukur tinggi dan berat badan dirancang lebih sederhana sehingga memudahkan waktu pemakaian. Untuk mengukur berat badan dengan berat maksimum 200kg sedangkan untuk mengukur tinggi dengan batasan maksimum 2 meter. Ini dengan pertimbangan bahwa ukuran tinggi badan manusia umumnya lebih kurang dari 2 meter. Dimensi dari rangka alat ukur tinggi dan badan yang dirancang dan dibangun dalam penelitian ini dapat dilihat pada Gambar 18

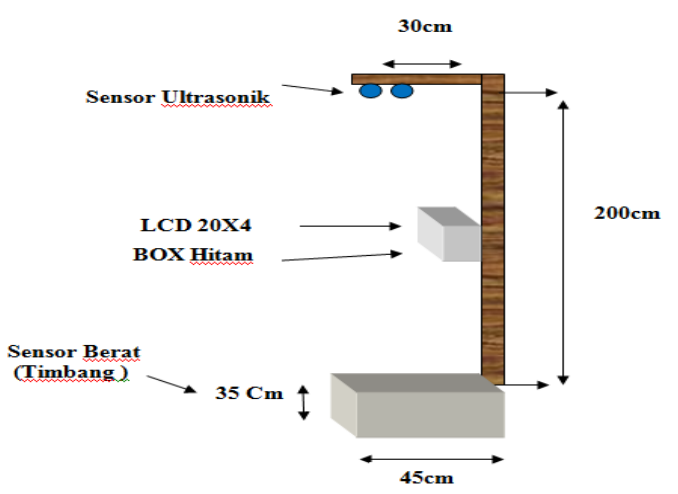

Gambar 18 Design Alat

Design alat merupakan rangkaian dari prototype alat Pengukur Tinggi dan Berat Badan Ideal yang digunakan untuk mengimplementasikan alat tersebut nantinya. Design tersebut dibuat untuk memudahkan proses pengerjaan alat yang akan dibuat. Dari design itu juga kita bisa tahu bahan-bahan dan peralatan apa saja yang dibutuhkan untuk membuat alat yang nantinya akan dibuat.

Bahan yang digunakan untuk membuatnya adalah dengan menggunakan balok kayu ukuran Panjang x Lebar $(45 \mathrm{~cm}$ x $35 \mathrm{~cm}$ ) yang digunakan untuk meletakkan 
Load Cell sebagai alat pengukur berat badan (timbangan), besi balok dengan panjang 2 meter sebagai tiang untuk mengukur tinggi badan, 1 buah benda padat sebagai penghalang permukaan kepala untuk memperakurat pengukuran dari sensor ultrasonik dan 1 buah kotak hitam untuk meletakkan peralatan elektronika yang digunakan serta 1 buah penyangga Sensor Ultrasonik.

\section{Tabel Jalur Rangkaian Pengukur Tinggi Badan}

Membuat rancangan rangkain pengukur tinggi badan membutuhkan beberapa peralatan elektronika, seperti LCD 20x4, Potensiometer, Arduino Uno R3, dan Sensor Ultrasonik HY-SRF04. Dimana untuk membuatnya, rangkaian elektronika tersebut harus dihubungkan satu dengan yang lainnya. Cara menghubungkannya adalah melalui koneksi port-port dari peralatan yang digunakan tersebut. Koneksi port-port yang digunakan pada perancangan rangkaian pengukur tinggi badan dapat dilihat pada tabel 1 berikut ini :

Tabel 1 Jalur Pin Rangkaian Pengukur Tinggi Badan

\begin{tabular}{|c|c|c|c|}
\hline LCD & Potensio & Arduino & Ultrasonik HY-SRF05 \\
\hline VSS & TERMINAL 1 & GND & GND \\
\hline VDD & TERMINAL 3 & 5V & VCC \\
\hline VO & TERMINAL 2 & - & - \\
\hline RS & - & PIN 12 & - \\
\hline R/W & TERMINAL 1 & GND & - \\
\hline E & - & PIN 11 & - \\
\hline- & - & PIN 7 & TRIGGER \\
\hline- & - & PIN 6 & ECHO \\
\hline DB4 & - & PIN 5 & - \\
\hline DB5 & - & PIN 4 & - \\
\hline DB6 & - & PIN 3 & - \\
\hline DB7 & - & PIN 2 & - \\
\hline A & TERMINAL 3 & 5V & - \\
\hline K & TERMINAL 1 & GND & \\
\hline & & & \\
\hline
\end{tabular}

\section{J. Perancangan Rangkaian Pengukur Berat Badan}

Berikut ini akan dijelaskan koneksi portport yang digunakan pada perancangan rangkaian pengukur berat badan, untuk lebih jelasnya dapat dilihat pada tabel 2 berikut ini

Tabel 2 Jalur Pin Rangkaian Pengukur Berat Badan

\begin{tabular}{|c|c|c|}
\hline HX711 & Arduino & Load Cell \\
\hline E+ & - & EKSITASI + (Red) \\
\hline E- & - & EKSITASI - (Black) \\
\hline A- & - & SINYAL - (Green) \\
\hline A + & - & SINYAL + (White $)$ \\
\hline VCC & VCC (5V) & - \\
\hline DT & A1 & - \\
\hline SCK & A0 & - \\
\hline GND & GND & - \\
\hline
\end{tabular}

\section{HASIL DAN PEMBAHASAN}

\section{A. Pengujian Sistem Pengukur Tinggi Dan Berat Badan Ideal}

Pengujian sistem pengukuran tinggi dan berat badan ideal dilakukan dengan percobaan terhadap sensor ultrasonik dan beberapa orang untuk mencari Index Mass Tubuh (IMT). Dengan menggunakan alat tersebut, pengukuran tinggi dan berat badan ideal dapat diketahui.

\section{B. Pengujian Sensor SRF-04}

Dalam pengujian pada sensor SRF 04 ini, dilakukan pengukuran jarak yang terbaca pada sensor dengan jarak sebenarnya. Sedangkan yang digunakan sebagai indikator jarak adalah kepala manusia sebagai obyek.

Pengujian sensor SRF-04 yaitu dengan mencari hubungan jarak dengan lama waktu tempuh (pulse). Berikut ini adalah data tabel hubungan antara jarak dengan waktu tempuh (pulse).

Tabel 3 Pengukuran Jarak Sensor Ultrasonik 


\begin{tabular}{|c|c|c|c|}
\hline No & Jarak yang diinginkan & Jarak sensor ping & Toleransi (\%) \\
\hline 1 & $10 \mathrm{Cm}$ & $10.09 \mathrm{Cm}$ & $0,89(\%)$ \\
\hline 2 & $20 \mathrm{Cm}$ & $20.10 \mathrm{Cm}$ & $0,49(\%)$ \\
\hline 3 & $30 \mathrm{Cm}$ & $30.12 \mathrm{Cm}$ & $0,39(\%)$ \\
\hline 4 & $40 \mathrm{Cm}$ & $40.13 \mathrm{Cm}$ & $0,32(\%)$ \\
\hline 5 & $50 \mathrm{Cm}$ & $50.15 \mathrm{Cm}$ & $0,29(\%)$ \\
\hline
\end{tabular}

Tabel diatas adalah hasil pengambilan data yang didapatkan dari sensor ultrasonik. Dapat kita amati tingkat kesalahan atau error yang diperoleh masih dibawah $1 \%$ untuk jarak setiap $10 \mathrm{~cm}$ nya.

\section{Pengujian Hasil Pengukuran} Berdasarkan Standart IMT

Pengujian sistem pengukuran tinggi badan dilakukan dengan membandingkan pengukuran tinggi dan berat badan menggunakan alat (modul) hasil perancangan terhadap pengukuran tinggi badan, dan menggunakan sebuah meteran. Hasil pengujian tersebut ditunjukkan pada Tabel 4 berikut ini.

Tabel 4 Pengujian tinggi dan berat badan

\begin{tabular}{|c|c|c|c|c|c|c|c|c|}
\hline \multirow{2}{*}{ Pengujian } & \multirow[b]{2}{*}{ Usia } & \multicolumn{2}{|c|}{ Tinggi $(\mathrm{cm})$} & \multicolumn{2}{|c|}{ Berat $(\mathrm{kg})$} & \multicolumn{2}{|c|}{ Error\% } & \multirow{2}{*}{ IMT } \\
\hline & & T.S & T.A & B.S & B.A & Tingg & Berat & \\
\hline Pertama & 19 & 163 & 163 & 48,8 & 48,8 & $0 \%$ & $0 \%$ & Kurus \\
\hline Kedua & 25 & 170 & 170 & 50,8 & 51 & $0 \%$ & $0,2 \%$ & Kurus \\
\hline Ketiga & 21 & 164 & 163 & 51 & 50,8 & $1 \%$ & $0,2 \%$ & Ideal \\
\hline Keempat & 20 & 160 & 159 & 55,9 & 56 & $1 \%$ & $0,01 \%$ & Ideal \\
\hline Kelima & 18 & 155 & 155 & 45 & 45,2 & $0 \%$ & $0,2 \%$ & Ideal \\
\hline Keenam & 20 & 160 & 161 & 50,5 & 50,6 & $1 \%$ & $0,1 \%$ & Ideal \\
\hline Ketujuh & 23 & 168 & 168 & 58 & 58 & $0 \%$ & $0 \%$ & Gemuk \\
\hline Kedelapan & 18 & 150 & 150 & 45 & 44,9 & $0 \%$ & $0,1 \%$ & Ideal \\
\hline Kesembilan & 21 & 164 & 162 & 50 & 50 & $2 \%$ & $0 \%$ & Ideal \\
\hline Kesepuluh & 23 & 168 & 169 & 75 & 74,7 & $1 \%$ & $0,3 \%$ & Gemuk \\
\hline
\end{tabular}

Keterangan :

T.S : Tinggi obyek yang sebenarnya

T.A : Tinggi pengukuran obyek dengan alat

\section{B.S : Berat obyek yang sebenarnya}

\section{B.A : Berat pengukuran obyek dengan alat}

Pengujian alat ini berupa pengujian terhadap tinggi dan berat badan manusia dengan memperbandingkan pengukuran terhadap alat dan secara manual. Pengujian alat dilakukan dengan 10 kali percobaan terhadap pemakai yang berbeda dimana untuk setiap orang dilakukan satu kali pengukuran. Dengan menganalisis hasil pengujian yang disajikan dalam Tabel 4.3, maka diperoleh kinerja alat pengukur tinngi dan berat badan ideal sebagai berikut. Tingkat keberhasilan rata-rata pada pengukuran tinggi badan adalah $0,1 \%$. Dengan demikian, maka sesuai dengan kriteria yang ditetapkan dalam Tabel 2.2, dapat dinyatakan bahwa dengan nilai IMT dibawa <18,5 maka dinyatakan kekurangan berat dan bilah IMT diatas 18,5-24,9 dinyatakan sebagai ideal. Maka untuk mencari IMT (Index mass Tubuh) digunakan rumus persamaan yaitu :

$$
\mathrm{IMT}=\frac{\text { Berat Badan }(\mathrm{Kg})}{\text { Tinggi Badan }(\mathrm{m})^{2}}
$$

\section{Flowchart Program}

Penyusunan flowchart begitu penting dalam merancang program yang akan dilakukan, itu dikarenakan untuk mempermudah dalam melakukan inisialisasi terhadap rangkaian program yang akan dibuat, Adapun Flowchart dari program yang akan dibuat dapat dilihat pada gambar 19 berikut ini. 


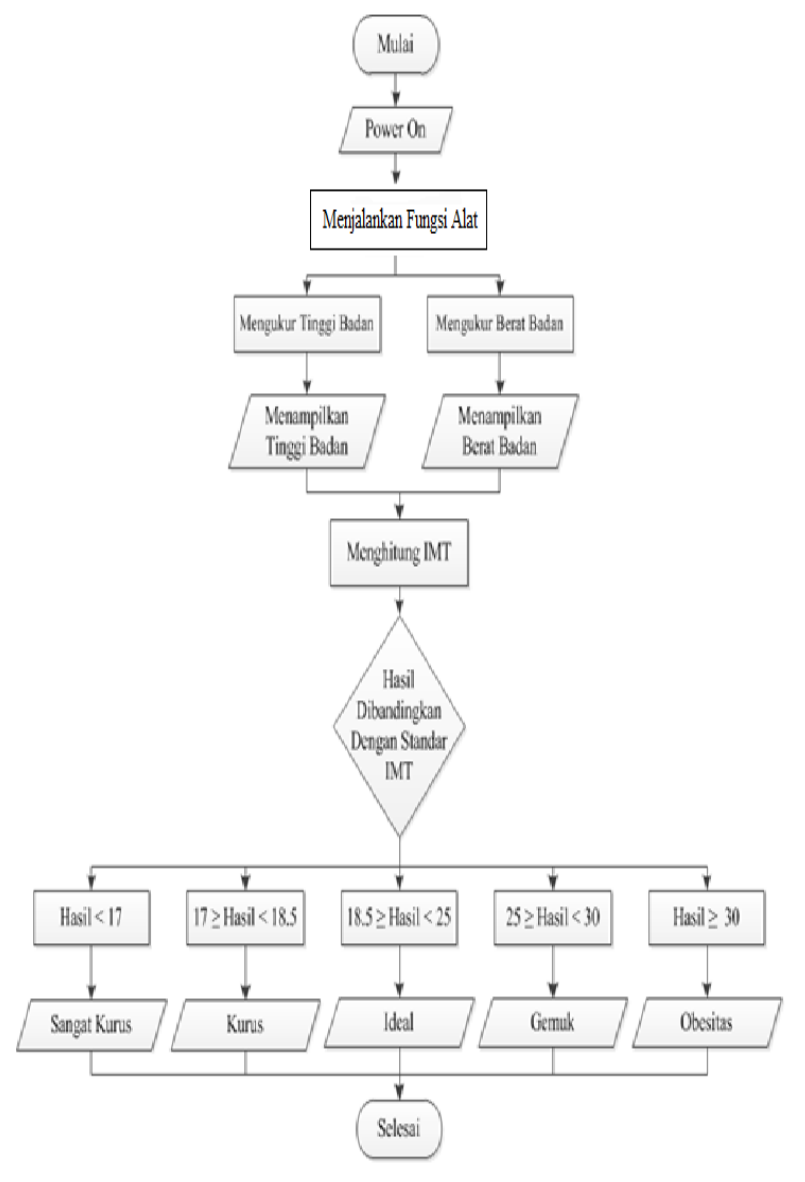

Gambar 19 Flowchart Program

\section{Kesimpulan Saran}

\section{A. Kesimpulan}

Kesimpulan yang dapat diambil dari pembuatan alat pengukur tinggi dan berat badan ideal berbasis arduino ini adalah sebagai berikut;

Alat pengukur tinggi badan dan berat badan ideal ini merupakan gabungan antara alat pengukur tinggi dan berat badan. Masing-masing alat tersebut menggunakan sensor yang berbeda yaitu Sensor Ultrasonik HY-SRF04 dan Load Cell. Arduino digunakan sebagai otak atau control perintah dari 2 buah sensor tersebut. Cara menggabungkan 2 buah sensor yang berbeda dengan arduino adalah dengan mengatur setiap port yang digunakan. Hal ini dimaksudkan supaya tidak terjadi benturan dari port antara 2 buah sensor yang tersambung pada arduino tersebut. Dengan error dibawah $1 \%$.

\section{B. Saran}

Berdasarkan percobaan yang telah dilakukan dan hasil yang telah dicapai pada penelitian ini, ternyata masih terdapat kekurangan pada sistem ini, selanjutnya ada beberapa saran yang bisa dikembangkan lebih lanjut diantaranya :

1. Mekanikal untuk alat ukur dapat ditingkatkan lagi akurasinya dengan menambahkan casing atau penyanggah yang kuat.

2. Display untuk menampilkan hasil pengukuran dapat diganti dengan display warna atau dengan ukuran yang lebih besar, sehingga pembacaan hasil ukurnya akan lebih jelas dan efektif.

\section{DAFTAR PUSTAKA}

1. Alviansyah, "Potensiometer". http://potensiometer.html. Di akses tanggal 15 Februari 2014. \{16/04/2018\}

2. Arifin Jainudin "Apa Itu Load Cell Raja Load Cell. ". Aviable http://www.rajaloadcell.com/article/apa-ituload-cell--8.\{16/04/2018\}

3. Anonim, 2012. "LCD (Liquid Crystal Disiplay)". http://elektronikadasar.web.id/ lcd-liquidcristal-display/\{16/04/2018\}

4. A. L. Khakim, "Rancang Bangun Alat Timbang Digital Berbasis AVR Tipe 
Atmega32. Tugas Akhir. Universitas Negeri Semarang". Aviable www.Tugas AkhirUniversitas Negeri Semarang. $\{16 / 4 / 2018\}$

5. Anonim, "Pin Header for arduino" Aviable http://pinheader.com. \{16/04/2018\}

6. Djuandi, Feri. "Pengetian Arduino UNO Mikrokontroller ATMega328". .Aviable http://www.caratekno.com/2015/07/pengerti an-arduino-uno-mikrokontroler.html . $\{16 / 04 / 2018\}$

7. M.U. Arief. "Pengujian Sensor Ultrasonik PING untuk Pengukuran Level.Ketinggian dan Volume Air, Jurnal Ilmiah "Elektrikal Enjiniring" Aviable http://www.UltrasonicSensor.PING.com.\{16 $/ 4 / 2018\}$

8. RI. Departemen Kesehatan"Petunjuk Teknis Pemantauan Status Gizi Orang Dewasa dengan Indeks Massa Tubuh(IMT)", $\quad$ Aviable from:http://www.depkes.go.id/index.php.vw $=2 \& \mathrm{id}=\mathrm{A}-137\{16 / 04 / 2018\}$

9. Syah, Efran. "Kalkulator IMT, Ukur Berat Badan Anda". Aviable http://www.medkes.com/2013/11/kalkulatorimt-ukur-berat-badan-ideal.html. $\{16 / 04 / 2018\}$ 